Chapter 1

\title{
Executive Summary-2003
} Assessment of Undiscovered Oil and Gas Resources in the Upper Cretaceous Navarro and Taylor Groups, Western Gulf Province, Gulf Coast Region, Texas

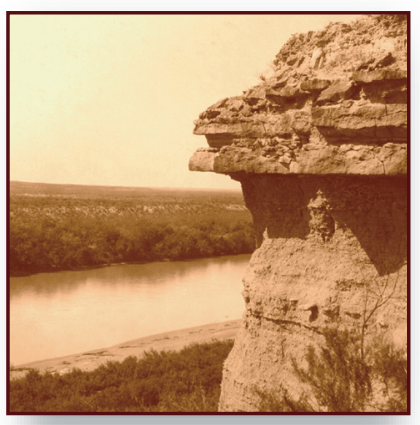

Click here to return to Volume Title Page

By U.S. Geological Survey Western Gulf Province Assessment Team

Chapter 1 of

Petroleum Systems and Geologic Assessment of Undiscovered Oil and Gas, Navarro and Taylor Groups, Western Gulf Province, Texas

By U.S. Geological Survey Western Gulf Province Assessment Team

U.S. Geological Survey Digital Data Series DDS-69-H

U.S. Department of the Interior

U.S. Geological Survey 


\section{U.S. Department of the Interior \\ P. Lynn Scarlett, Acting Secretary}

\section{U.S. Geological Survey P. Patrick Leahy, Acting Director}

U.S. Geological Survey, Reston, Virginia: 2006

For product and ordering information:

World Wide Web: http://www.usgs.gov/pubprod

Telephone: 1-888-ASK-USGS

For more information on the USGS — the Federal source for science about the Earth, its natural and living resources, natural hazards, and the environment:

World Wide Web: http://www.usgs.gov

Telephone:1-888-ASK-USGS

Any use of trade, product, or firm names is for descriptive purposes only and does not imply endorsement by the U.S. Government.

Although this report is in the public domain, permission must be secured from the individual copyright owners to reproduce any copyrighted materials contained within this report.

Suggested citation:

U.S. Geological Survey Western Gulf Province Assessment Team, 2006, Executive summary—2003 assessment of undiscovered oil and gas resources in the Upper Cretaceous Navarro and Taylor Groups, Western Gulf Province, Gulf Coast region, Texas: U.S. Geological Survey Digital Data Series DDS-69-H, Chapter 1, 3 p. 


\section{Contents}

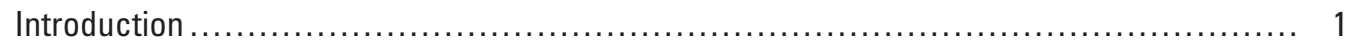

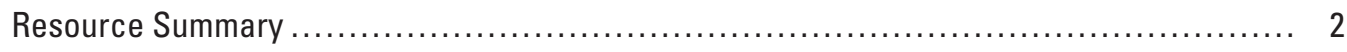

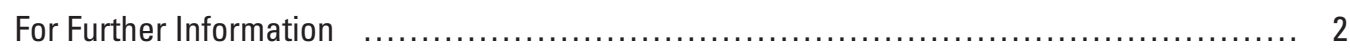

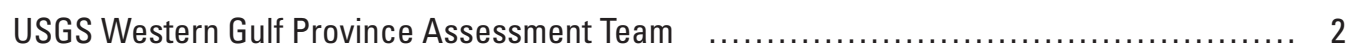

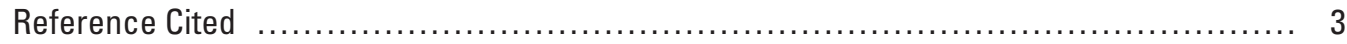

\section{Figure}

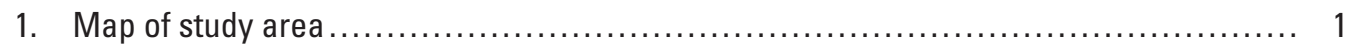

\section{Table}

1. Assessment results summary 


\title{
Executive Summary-2003 Assessment of Undiscovered Oil and Gas Resources in the Upper Cretaceous Navarro and Taylor Groups, Western Gulf Province, Gulf Coast Region, Texas
}

\author{
By U.S. Geologic Survey Western Gulf Province Assessment Team
}

\section{Introduction}

The U.S. Geological Survey (USGS) recently completed an assessment of the undiscovered oil and gas potential of the Upper Cretaceous Navarro and Taylor Groups in the Western Gulf Province of the Gulf Coast region (fig. 1) as part of a national oil and gas assessment effort (USGS Navarro and Taylor Groups Assessment Team, 2004). The assessment of the petroleum potential of the Navarro and Taylor Groups was based on the general geologic elements used to define a total petroleum system (TPS), including hydrocarbon source rocks (source rock maturation, hydrocarbon generation and migration), reservoir rocks (sequence stratigraphy and petrophysical properties), and hydrocarbon traps (trap formation and timing). Using this geologic framework, the USGS defined five assessment units (AU) in the Navarro and Taylor Groups as parts of a single TPS, the Smackover-Austin-Eagle Ford Composite TPS: Travis Volcanic Mounds Oil AU, Uvalde Volcanic Mounds Gas and Oil AU, Navarro-Taylor Updip Oil and Gas AU, Navarro-Taylor Downdip Gas and Oil AU, and NavarroTaylor Slope-Basin Gas AU (table 1).

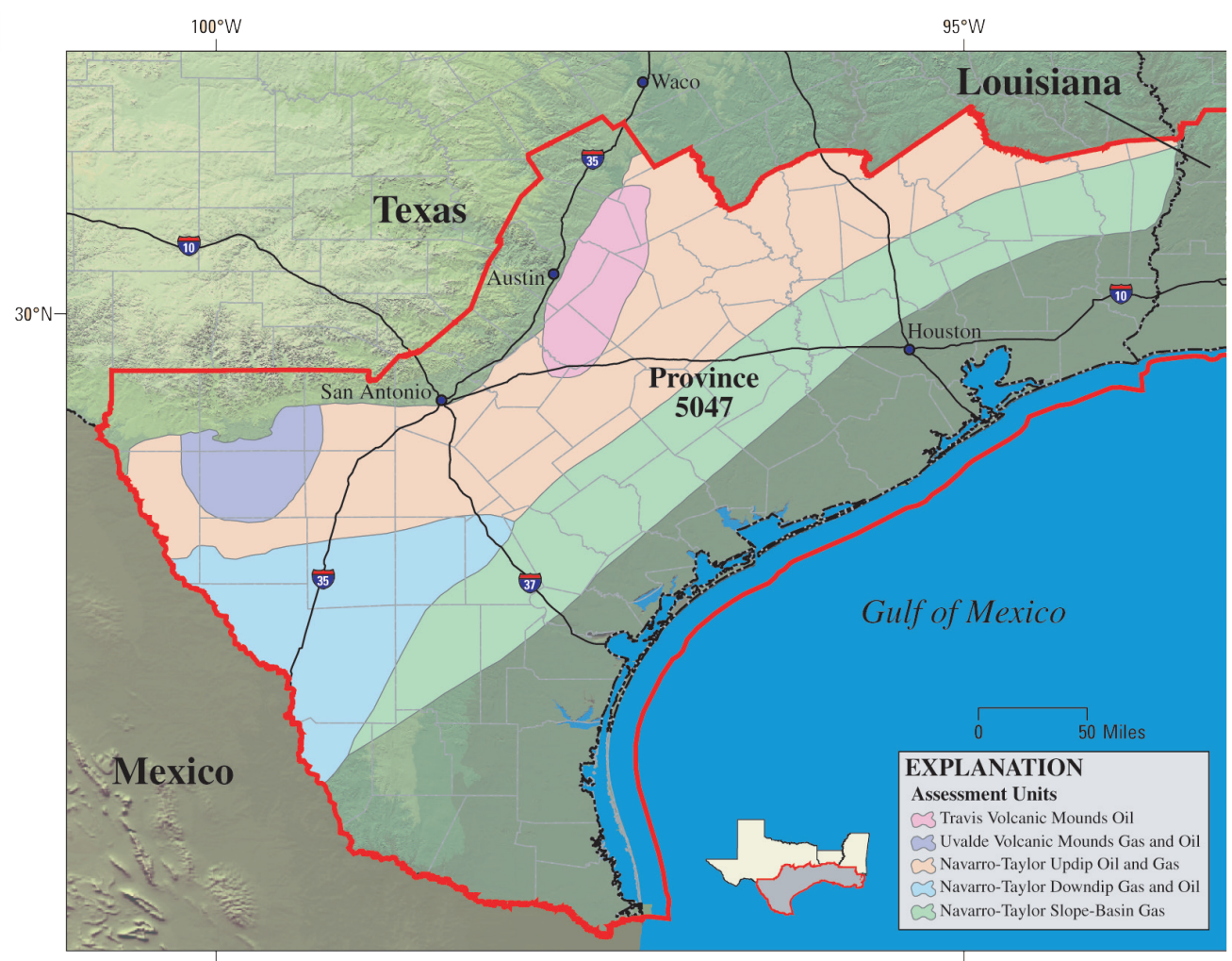

Figure 1. Map of the western part of Western Gulf Province 5047 of the Gulf Coast region (outlined in red), showing geographic distribution of assessment units in the Navarro and Taylor Groups of the Smackover-Austin-Eagle Ford Composite Total Petroleum System. 


\section{Resource Summary}

The USGS assessed undiscovered conventional oil and gas for each of the AUs, resulting in estimated means of 1,682.8 billion cubic feet of non-associated gas and associated gas in oil fields, 33.22 million barrels of oil, and 34.26 million barrels of natural gas liquids in the Smackover-Austin-Eagle Ford Composite TPS (table 1).
All of the undiscovered gas is conventional. The NavarroTaylor Slope-Basin Gas AU contains an estimated mean of 924.96 billion cubic feet of gas, representing about 55 percent of the total mean undiscovered gas resource (1,682.8 billion cubic feet) for the Navarro and Taylor Groups in the province.

Table 1. Smackover-Austin-Eagle Ford Composite Total Petroleum System, 504702, Assessment Results Summary

[MMBO, million barrels of oil. BCFG, billion cubic feet of gas. MMBNGL, million barrels of natural gas liquids. MAS, minimum accumulation size assessed (MMBO or BCFG). Prob., probability (including both geologic and accessibility probabilities) of at least one accumulation equal to or greater than the MAS. Accum., accumulation. Results shown are fully risked estimates. For gas accumulations, all liquids are included as natural gas liquids (NGL). F95 represents a 95-percent chance of at least the amount tabulated. Other fractiles are defined similarly. Fractiles are additive under the assumption of perfect positive correlation. Shading indicates not applicable]

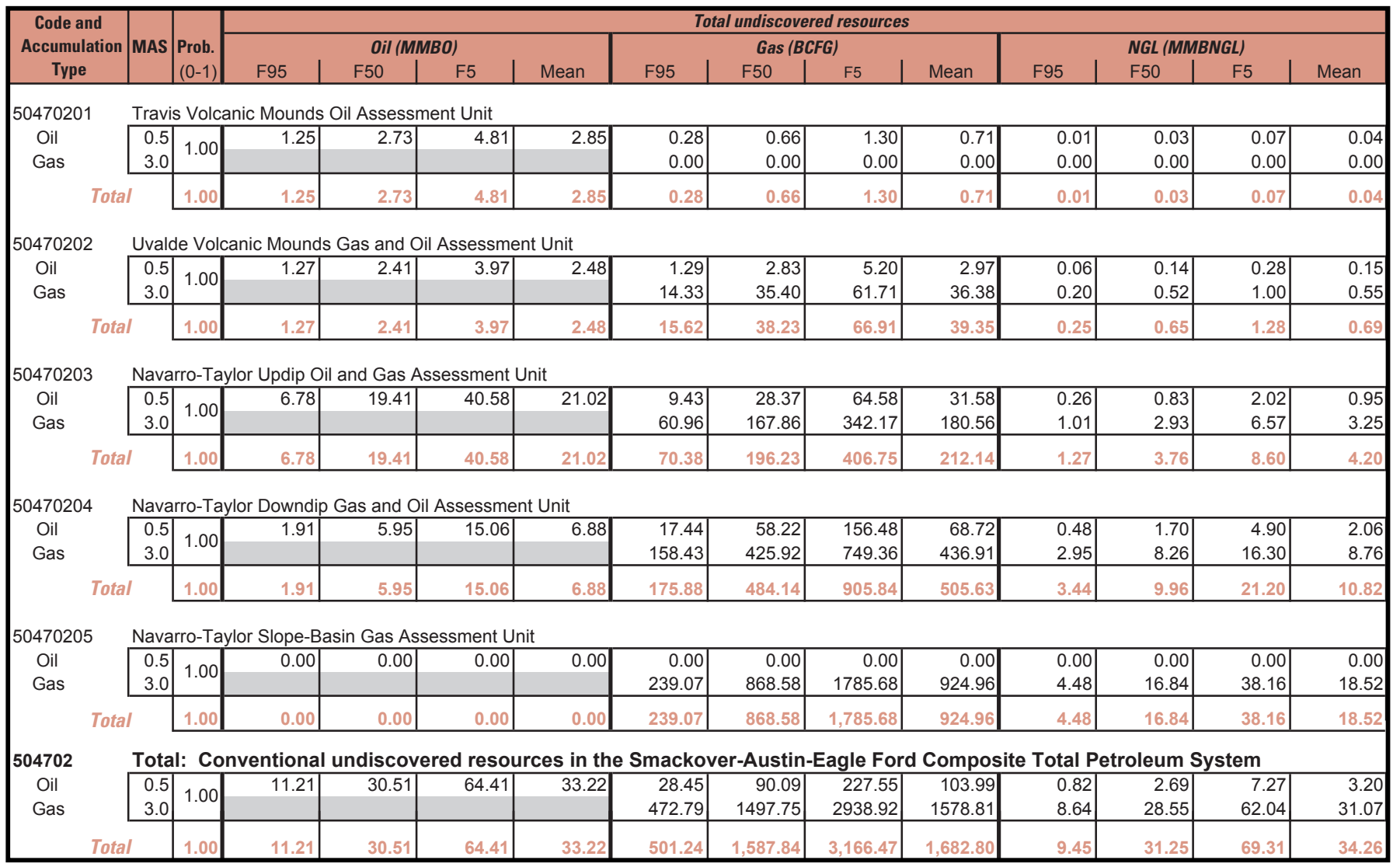

\section{For Further Information}

Geologic studies of total petroleum systems and assessment units and reports on the methodology used in assessing resources in the Navarro and Taylor Groups in the Western Gulf Province of the Gulf Coast region are available at the USGS Central Energy Team Web site: http://energy. cr.usgs.gov/oilgas/noga/

\section{USGS Western Gulf Province Assessment Team}

T.S. Dyman, S.M. Condon, R.R. Charpentier, T.A. Cook, T.R. Klett, M.D. Lewan, M.J. Pawlewicz, R.M. Pollastro, and C.J. Schenk. 


\section{Reference Cited}

USGS Navarro and Taylor Groups Assessment Team, 2004, 2003 assessment of undiscovered oil and gas resources in Upper Cretaceous Navarro and Taylor Groups, Western Gulf Province, Gulf Coast region, Texas: U.S. Geological Survey Fact Sheet FS-2004-3114, November 2004. [Also available at URL http://pubs.usgs.gov/fs/2004/3114/ last accessed on March 1, 2006]

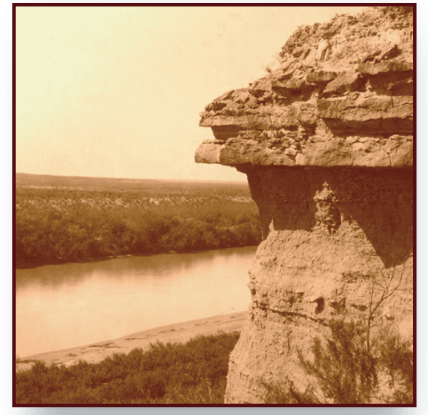

Click here to return to Volume Title Page 